\title{
ATR-FTIR Analysis of Adhesives Jointing Buddhist Scripture Scrolls in Medieval Korea(Goryeo Dynasty)
}

\author{
Joon Suk Oh \\ Conservation Laboratory, National Folk Museum of Korea, Seoul, 00345, Korea \\ ${ }^{1}$ Corresponding Author: kcommune@yahoo.co.kr, +82-2-3704-3276
}

\begin{abstract}
The adhesives joining Buddhist scripture scrolls from medieval Korea(Goryeo Dynasty, A.D. 918 1392) are different from wheat starch adhesive. The composition of the adhesive was analyzed using Attenuated Total Reflectance -Fourier Transform Infrared(ATR-FTIR) spectroscopy. In the adhesive used to join Buddhist scripture scrolls, peaks attributed to amide I and amide II of the protein and carbohydrate were detected in the ATR-FTIR spectra, and no carbonyl $\operatorname{peak}\left(1745 \mathrm{~cm}^{-1}\right)$ for oil was detected in the 2nd derivative ATR-FTIR spectra. The ATR-FTIR spectra almost coincided with those of defatted soybean powder adhesive. Hence, the adhesives joining Buddhist scripture scrolls were inferred to be soybean adhesive prepared from a defatted soybean cake.
\end{abstract}

Key Words: Medieval Korea, Adhesive joining Buddhist scripture scroll, ATR-FTIR, Soybean adhesive, Defatted soybean

\section{INTRODUCTION}

In East Asia, wheat starch adhesive, which is prepared from wheat flour, has been used in paper bonding or painting mounting, such as for painting backings made of paper or fabric, since ancient times. There are several records in ancient literature from Korea, China, and Japan on the use of wheat starch adhesive(Chun, 2006). Wheat starch adhesives have also been used in relics. Wheat starch adhesive prepared from flour has been used continuously since ancient times; consequently, its production techniques have advanced. Adhesives have been prepared from fermented wheat flour or fermented wheat starch for mountings of paintings and writings(Chun, 2006).

Besides wheat starch adhesive, there is some ancient literature describing the use of soybean adhesive(豆粘, 豆 糊, 大豆糊)(Okada and Akimoto, 1998; Chun, 2006; Cho et al., 2010; Hayakawa, 2014; Ohashi et al., 2016). However, the production methods of soybean adhesive are unknown, because this knowledge was not passed down the ages.

Soybean adhesive is only sparsely mentioned in ancient (正倉院文書: 8th century，延喜式: 927) or medieval Japanese literature(朝野群載: 平安時代 後期, 色葉字類抄: mid-late 12th century, 名語記: 1275), and ancient Chinese literature[賈思妿思(386 534) 齊民要術 裝㣴短論]. In Korea, it has only been mentioned in literature from the middle Joseon period(黃胤錫 願齋亂暮: 1776). Hence, one can infer that soybean adhesive was used in East Asia only until medieval times, and rarely used thereafter. According to the literature, a soybean adhesive was used(大豆, 黃豆) when joining paper or adhering thick paper. There are also some records on the preparation of adhesives by mixing wheat flour or glutinous rice flour with soy flour(Cho et al., 2010).

According to painting and paper conservators, there are brown discolored adhesives on paper joints in Buddhist scripture scrolls from the Goryeo Dynasty. These adhesives show different characteristics from wheat starch adhesive, because they do not swell in water and are very difficult to remove. These adhesives have been considered to be different from wheat starch adhesive, and assumed as soybean adhesive or fermented soybean adhesive, without a scientific composition analysis (Jang and Im, 2003; Lee, 2010). As these adhesives have never been scientifically analyzed in Korea, their precise composition has not been confirmed yet. Similar shapes and characteristics of adhesives have been found in adhesives of paper joints in 
Buddhist scriptures and books from the Nara Period(奈良時 代, 710 794) and Heian Period(本安時代, 794 1185) of Japan. They have been identified as soybean adhesive, by associating material analysis results with the literature (Okada and Akimoto, 1998; Hayakawa, 2014; Ohashi et al., 2016).

In Korea, the adhesive used in the joints of Buddhist scripture scrolls from the Goryeo Dynasty is regarded different from wheat starch adhesive, but it is assumed to be soybean adhesive or fermented soybean adhesive without scientific composition analysis of the adhesive joining Buddhist scripture scrolls from the Goryeo Dynasty(Jang and Im, 2003; Lee, 2010). Therefore, this study attempts to identify the components of the adhesives joining Buddhist scripture scrolls from the Goryeo Dynasty, and hence, determine the production methods.

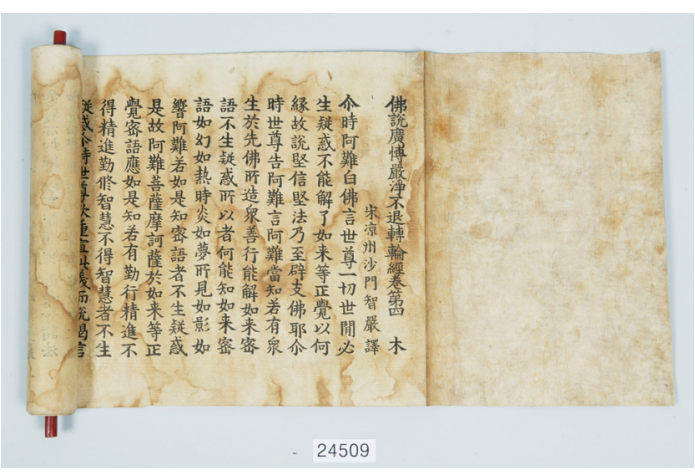

Figure 1. The First Tripitaka Koreana Edition, Avaivartika Cakra Sutra, Volume 4(Folk 24509).

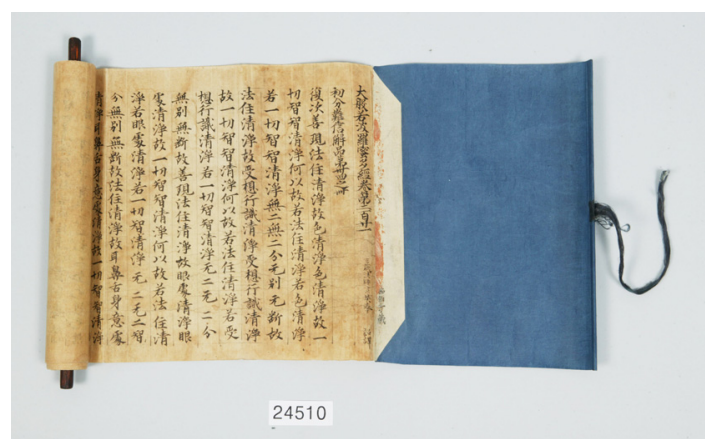

Figure 2. The First Tripitaka Koreana Edition, Maha Prajnaparamita Sutra, Volume 221(Folk 24510).

\section{EXPERIMENTAL}

\subsection{Adhesives joining Buddhist scripture scrolls from the Goryeo Dynasty}

The adhesives analyzed in this study were the adhesives joining Buddhist scripture scrolls that had peeled off from The First Tripitaka Koreana Edition, Avaivartika Cakra Sutra, Volume 4(佛說廣博嚴淨不退轉輪經 卷 第四, 11th century, Folk 24509)(Figure 1) and Maha Prajnaparamita Sutra, Volume 221(大般若波羅蜜多經 卷二百二十一，11th century, Folk 24510)(Figure 2) owned by National Folk Museum of Korea; Avatamsaka Sutra, Volume 37(大方廣佛 華嚴經 晋本 卷三十七, 1098, National Treasure No.202) (Figure 3) owned by Adan Mungo Foundation; The First Tripika Koreana Edition, Abhidharma vibhasa Sastra, Volumes 11(初雕本阿毗曇毗婆沙論 卷11，12th century, National Treasure No.268)(Figure 4) owned by Horim Museum. Peeled-off adhesives joining the Buddhist scriptures with no attached paper fibers when observed with a microscope, were used for the analysis. These adhesives appeared discolored and brown at the joints(Figures 5, 6).

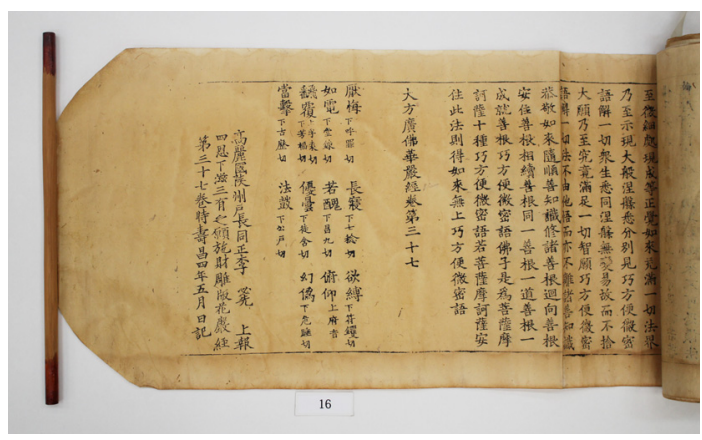

Figure 3. Avatamsaka Sutra, Volume 37.

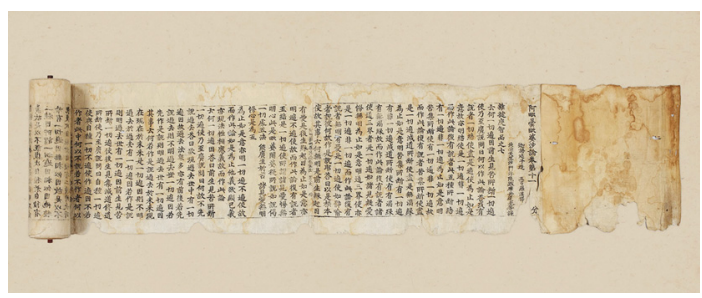

Figure 4. The First Tripitaka Koreana Edition, Abhidharma vibhasa Sastra, Volume 11. 


\subsection{Vegetable raw materials and adhesives}

For reference, to help with the identification, soybean powder(Taepyeong, Korea), defatted soybean powder (Hokyung Tech, India), and mung bean powder(Malgundle, Korea) were employed among bean flours, and wheat flour(Dongil, USA), rice flour(Korea), and glutinous rice flour(Gaon Food, Korea) were employed among grain flours. Among these raw materials, the soybean powder and defatted soybean powder were stirred at $70 \sim 80^{\circ} \mathrm{C}$ for $5 \sim 20 \mathrm{~min}$ to prepare adhesive pastes.

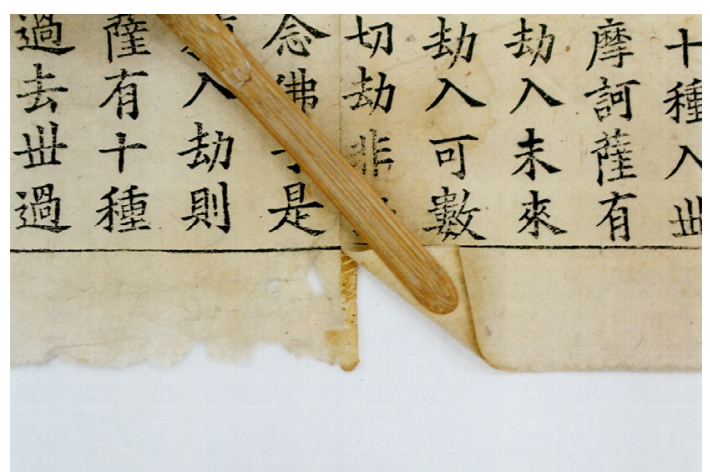

Figure 5. Brown adhesive used to join papers of Buddhis scripture, Avatamsaka Sutra, Volume 37.

\subsection{High temperature and high humidity treatment}

The adhesive pastes prepared with the soybean and defatted soybean powders were dried for one week. Then, they were treated at a temperature of $80^{\circ} \mathrm{C}$ and a relative humidity of $80 \%$ for 10 days in a temperature and humidity chamber(JFM Engineering, Korea).

\subsection{Analysis}

The adhesives joining the Buddhist scripture scrolls

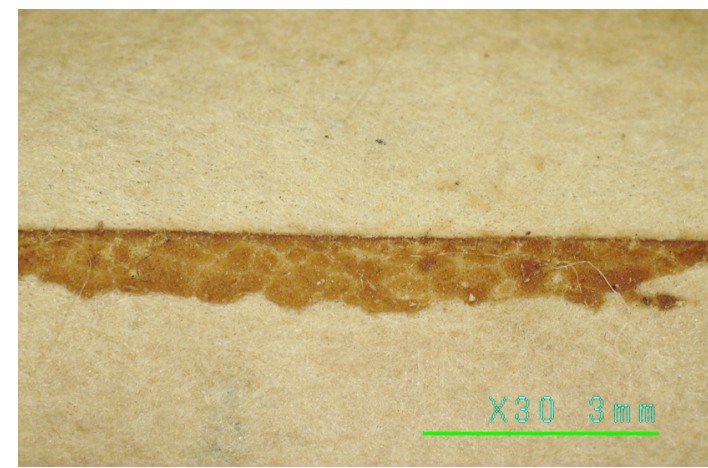

Figure 6. Brown adhesive used to join papers of Buddhist scripture, The First Tripitaka Koreana Edition, Avaivartika Cakra Sutra, Volume 4(Folk 24509).

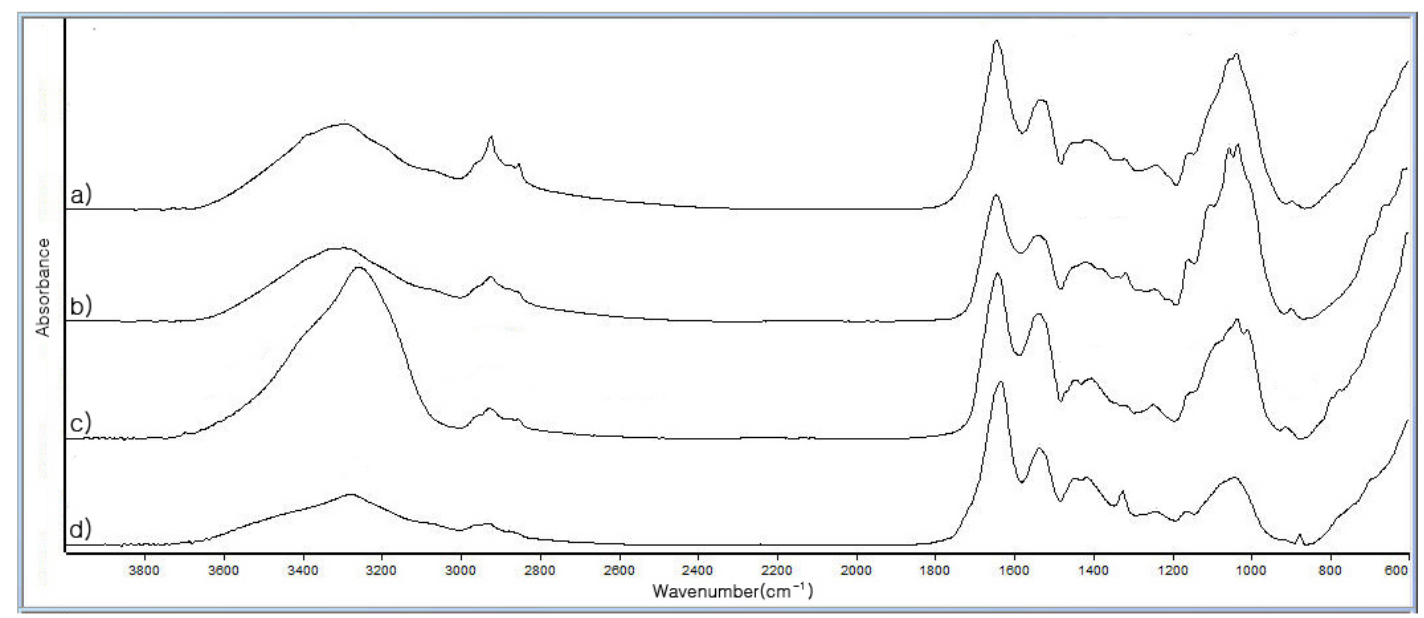

Figure 7. ATR-FTIR spectra of adhesives used to join papers of Buddhist scriptures. a) The First Tripitaka Koreana Edition, Avaivartika Cakra Sutra, Volume 4(Folk 24509), b) The First Tripitaka Koreana Edition, Maha Prajnaparamita Sutra, Volume 221(Folk 24510), c) Avatamsaka Sutra, Volume 37, d) The First Tripitaka Koreana Edition, Abhidharma vibhasa Sastra, Volume 11. 
from the Goryeo Dynasty, as well as those prepared from the grain and bean flours, were analyzed using Attenuated Total Reflectance-Fourier Transform Infrared(ATR-FTIR) spectroscopy. The samples were placed on a Ge crystal mirror and measured in the ATR mode with a microscope (Hyperion 2000, Bruker, Germany) attached to the infrared spectroscope(Vertex 80v, Bruker, Germany) at a scan number of 64 and resolution of $4 \mathrm{~cm}^{-1}$. Thus, ATR-FTIR spectra were obtained for a relative humidity of $10-20 \%$. The 2nd derivative ATR-FTIR spectra were obtained by smoothing point 9 by the Savitzky-Golay algorithm.

The ATR-FTIR spectra for adhesives joining the Buddhist scripture scrolls from the Goryeo Dynasty, soybean powder, defatted soybean powder, mung bean powder, wheat flour, rice flour, and glutinous rice flour were acquire in relative humidity of $10 \sim 20 \%$. Furthermore, the ATR-FTIR spectra for adhesives produced with soybean powder and defatted soybean powder were acquired in relative humidity of $10 \sim 20 \%$ after drying for one week.

\section{RESULTS AND DISCUSSION}

\subsection{ATR-FTIR spectra of adhesives joining Buddhist scripture scrolls from the Goryeo Dynasty}

The ATR-FTIR spectra of the four adhesives joining Buddhist scripture scrolls from the Goryeo Dynasty are shown in Figure 7. Therein, the $1632 \sim 1643 \mathrm{~cm}^{-1}$ peak is assigned to Amide I, $1532 \sim 1535 \mathrm{~cm}^{-1}$ is assigned to Amide II, and $1240 \sim 1246 \mathrm{~cm}^{-1}$ is assigned to Amide III, which are typical protein peaks(Wang, et al., 2005). The strong absorption peak at $1200 \sim 900 \mathrm{~cm}^{-1}$ is attributed to the C-C and $\mathrm{C}-\mathrm{O}$ stretching vibrations of carbohydrate. These spectra indicate a high concentration of proteins. Therefore, the adhesives joining the Buddhist scripture scrolls are not animal glues with protein components or wheat starch adhesives with carbohydrate components, which are typically used to join papers. They are inferred to be derived from grains or beans that contain both protein and carbohydrate(Rural Development Administration, National Institute of Agricultural Sciences, 2013). These FT-IR spectra match those of the brown adhesives identified as soybean adhesive used in Buddhist scriptures during the Heian period in Japan, which coincides with the Goryeo Dynasty(Hayakawa, 2014; Ohashi et al., 2016). Furthermore, the reduction of the Amide II peak and the superposed appearance with the Amide I peak, which occur in the fermented soybean adhesive, are not apparent here(Lee, 2010). This indicates that the adhesives joining Buddhist scripture scrolls from the Goryeo Dynasty are not fermented soybean adhesives.

\subsection{Comparison of ATR-FIR spectra between grains and beans}

Grains such as wheat, rice, glutinous rice, barley, buckwheat, and corn contain approximately $70 \sim 80 \%$ carbohydrates such as starch, but only a small amount of proteins(less than $10 \%)$. On the other hand, beans such as red beans, mung beans, and peas contain approximately $60 \%$ carbohydrates such as starch and 20\% proteins. Among the beans, soybeans contain approximately 30\% carbohydrates, $40 \%$ proteins, and 18\% lipids(oil); hence, they have a higher protein content than carbohydrate content. The protein contents of soybeans are much higher compared to those of grains and other beans(Rural Development Administration, National Institute of Agricultural Sciences, 2013).

The ATR-FTIR spectra of the grain(rice, wheat, glutinous rice) and bean(mung bean, soybean, defatted soybean) powders are shown in Figure 8. In the spectra of rice, wheat, glutinous rice, and mung bean powders with high carbohydrate contents, the peak intensities for the $1641 \mathrm{~cm}^{-1}$ peak of Amide I and $1543 \mathrm{~cm}^{-1}$ peak of Amide II for protein are weak, but those assigned to the $\mathrm{C}-\mathrm{C}$ and $\mathrm{C}-\mathrm{O}$ stretching vibrations of carbohydrate are strong at $1014 \sim 1020 \mathrm{~cm}^{-1}$, 1079 1080 $\mathrm{cm}^{-1}$, and 1149 $1150 \mathrm{~cm}^{-1}$ (Wilson and Belton, 1988). In contrast, in the spectrum of soybean powder, which has a higher protein content than carbohydrate content, the Amide I and Amide II peaks of protein are distinct at $1641 \mathrm{~cm}^{-1}$ and $1543 \mathrm{~cm}^{-1}$. Furthermore, in the region of $1200 \sim 900 \mathrm{~cm}^{-1}$, one strong peak with a shoulder where the peak of the carbohydrate has not fully separated, is apparent. At $1745 \mathrm{~cm}^{-1}$, the carbonyl group peak of lipids is apparent with a small shoulder. In the spectrum of the 
defatted soybean powder, wherein the lipid from soybean has been removed, the carbonyl group peak of the lipid does not appear(Figure 8f). The ATR-FTIR spectra of the adhesives prepared by heating the soybean powder and defatted soybean powder are shown in Figure 9. Similar to the spectra of soybean powder and defatted soybean powder before heating, peaks corresponding to proteins and carbohydrates are clear. The ATR-FTIR spectra of the adhesives joining Buddhist scripture scrolls from the Goryeo Dynasty are similar to those of soybean powder and defatted soybean powder. The latter exhibit clearer peaks for proteins and carbohydrates than other grain or bean powders with high carbohydrate contents. The peaks for lipids are not observed as with the defatted soybean

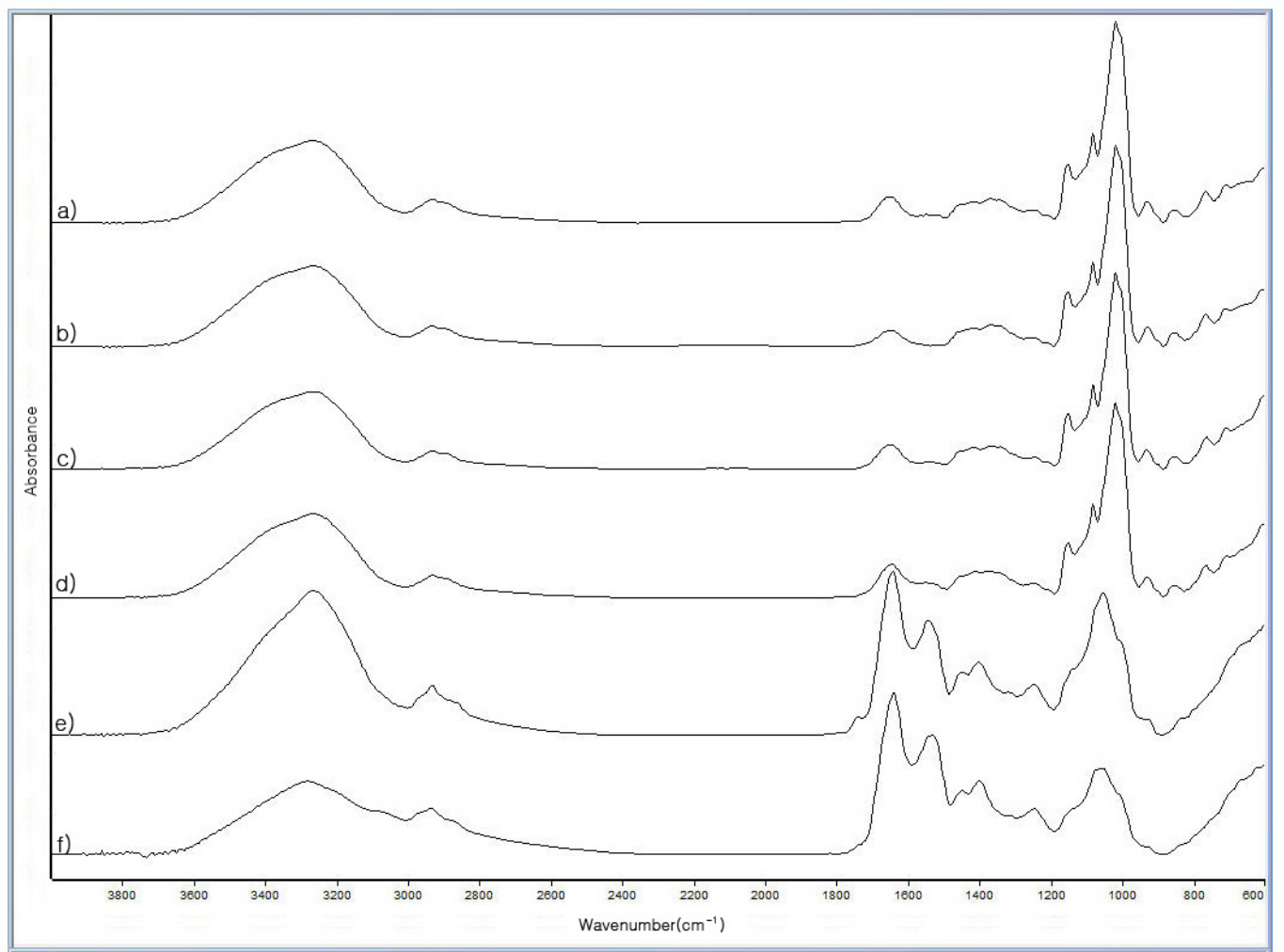

Figure 8. ATR-FTIR spectra of grain and bean powders. a) Rice, b) Wheat, c) Glutinous rice, d) Mung bean, e) Soybean, f) Defatted soybean.

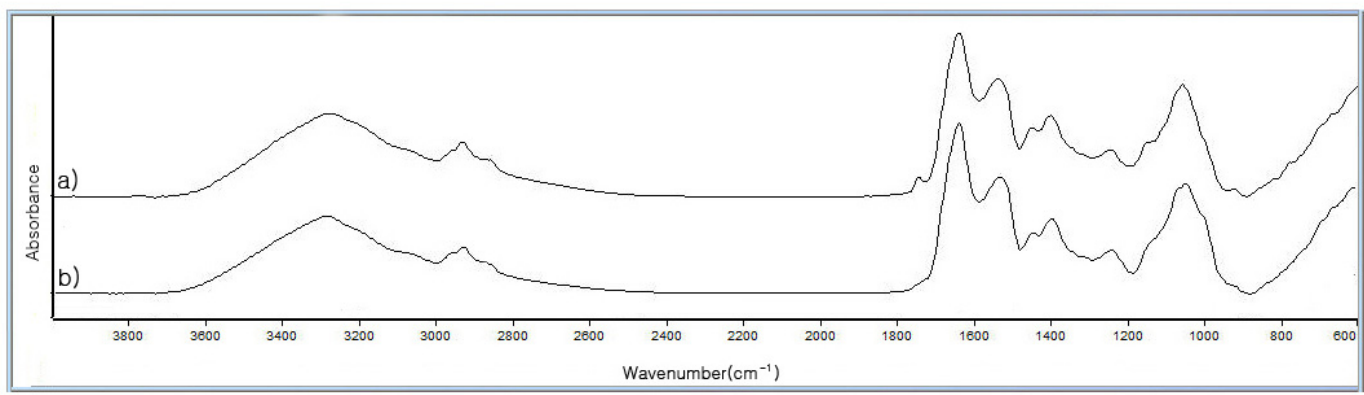

Figure 9. ATR-FTIR spectra of adhesives from a) Soybean powder, b) Defatted soybean powder. 
powder. Therefore, the adhesives joining Buddhist scripture scrolls from the Goryeo Dynasty are soybean adhesives made of defatted soybean powder from which lipids have been removed.

\subsection{Comparison of 2 nd derivative $A T R-T R R$ spectra between adhesives joining Buddhist scripture scrolls and soybean adhesive}

The 2nd derivative ATR-FTIR spectra(Figure 10) were used to analyze the inclusion of lipids in the adhesives

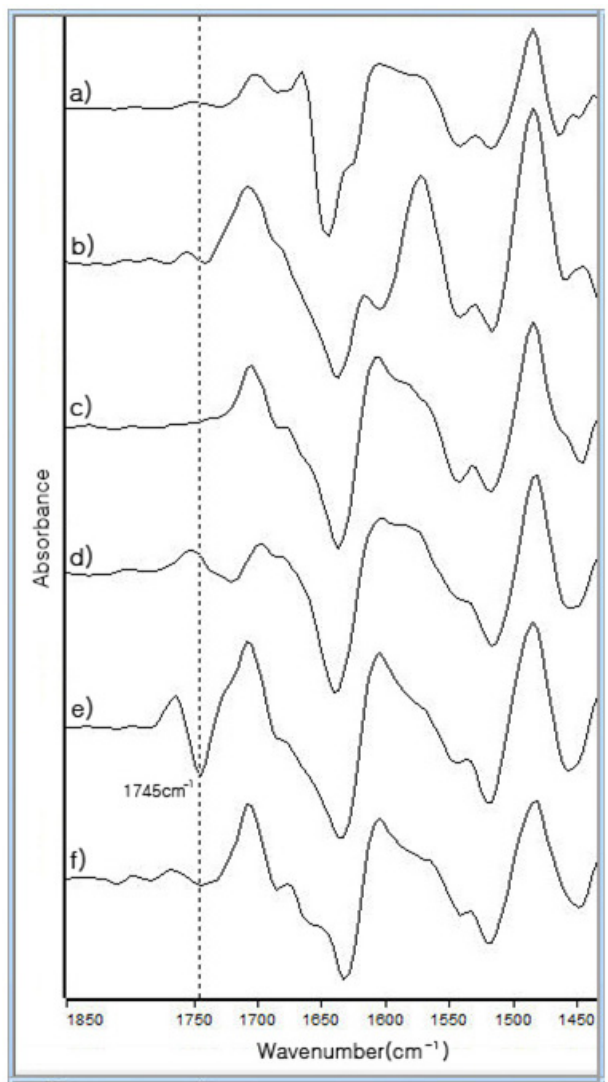

Figure 10. 2nd derivative ATR-FTIR spectra of adhesives for joining Buddhist scripture scrolls. a) The First Tripitaka Koreana Edition, Avaivartika Cakra Sutra, Volume 4 (Folk 24509) b) The First Tripitaka Koreana Edition, Maha Prajnaparamita Sutra, Volume 221 (Folk 24510), c) Avatamsaka Sutra, Volume 37, d) The First Tripitaka Koreana Edition, Abhidharma vibhasa Sastra, Volume 11, e) Soybean adhesive, f) Defatted soybean adhesive. joining Buddhist scripture scrolls from the Goryeo Dynasty, the soybean adhesive treated under high temperature and high humidity, and the defatted soybean adhesive, and whether the carbonyl group peak of the lipids was suppressed by the Amide I peak. The spectrum for the soybean powder adhesive(Figure 10e) clearly shows the carbonyl group peak for lipids at $1745 \mathrm{~cm}^{-1}$. However, in the spectrum for the defatted soybean powder adhesive (from which lipids have been removed), shown in Figure 10 $\mathrm{f}$, the carbonyl group peak for lipids is hardly observed. This peak is also not observedI in the 2nd derivative

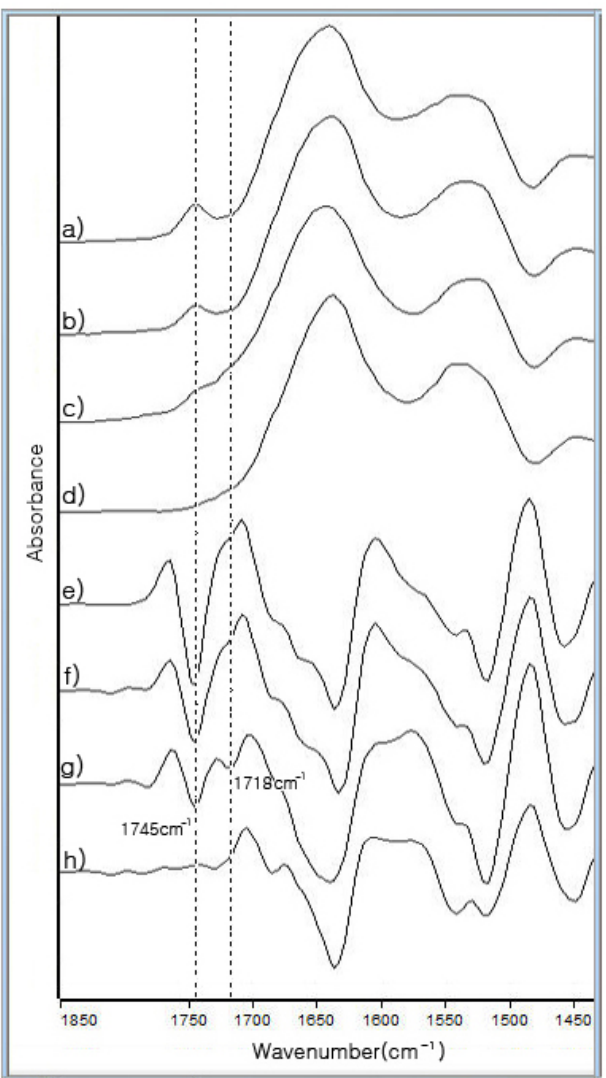

Figure 11. ATR-FTIR spectra of a) Soybean powder adhesive deteriorated at high temperature $\left(80^{\circ} \mathrm{C}\right)$ and high humidity $(80 \%$ ) for b) 1 day, c) 10 days, d) The First Tripitaka Koreana Edition, Maha Prajnaparamita Sutra, Volume 221(Folk 24510); 2nd derivative ATR-FTIR spectra of e) Soybean powder adhesives deteriorated at high temperature $\left(80^{\circ} \mathrm{C}\right)$ and high humidity $(80 \%)$ for $\left.\mathrm{f}\right)$ 1 day, g) 10 days, h) The First Tripitaka Koreana Edition, Maha Prajnaparamita Sutra, Volume 221(Folk 24510). 
ATR-FTIR spectra for the adhesives joining Buddhist scripture scrolls from the Goryeo Dynasty(Figure 10a d). This suggests that soybean adhesives with no lipids were used to join these scrolls.

Hayakawa attributed the absence of the carbonyl group peak for lipids in the FTIR spectra of the adhesives joining the scrolls, to the difference in the contents of soybean and lipid in modern times, or the degradation of the lipids over time(Hayakawa, 2014). Furthermore, Ohashi et al. reported that when soybean adhesive is deteriorated by accelerated ageing in a high temperature and high humidity environment $\left(80^{\circ} \mathrm{C}, 65 \%\right)$ over a long period of time, the strength of the carbonyl group peak $\left(1744 \mathrm{~cm}^{-1}\right)$ of lipids in the soybean adhesive decreases. They argued that the peak could have combined with the Amide I peak and disappeared, because carbonyl compounds such as aldehyde and carboxylic acid were increasingly formed in the low-wavelength region $\left(1680 \sim 1740 \mathrm{~cm}^{-1}\right)($ Ohashi et al., 2016). Under the aforementioned conditions of accelerated aging, the carbonyl group peak $\left(1744 \mathrm{~cm}^{-1}\right)$ for lipids decreases and disappears in the widening Amide I peak at $1641 \mathrm{~cm}^{-1}$, as suggested by Ohashi et al.(2016)(Figure 11a, b, c). In the 2nd derivative specta, the carbonyl group peak for lipids $\left(1745 \mathrm{~cm}^{-1}\right)$ weakens, and that of a new carbonyl compound appears at $1718 \mathrm{~cm}^{-1}$, which is a product of the high temperature and high humidity deterioration(Figure 11e, f, g). However, in the 2nd derivative spectrrum of the adhesives joining Buddhist scripture scrolls from the Goryeo Dynasty, the carbonyl group peak for lipids $\left(1745 \mathrm{~cm}^{-1}\right)$ and that of the carbonyl compound $\left(1718 \mathrm{~cm}^{-1}\right)$ are not observed at all (Figure 11h). This indicates that the carbonyl group peak for lipids does not disappear by deterioration over time. Thus, it can be concluded that the adhesives joining Buddhist scripture scrolls from the Goryeo Dynasty were not prepared directly from soybean, but were produced from materials like soybean cake which remains after the oil has been completely squeezed out from soybeans.

\section{CONCLUSIONS}

The adhesives joining Buddhist scripture scrolls from the Goryeo Dynasty show different characteristics than those of wheat starch adhesive, and the literature suggests that they have been used in Japan, and to join papers of Buddhist scriptures or books. The composition of the adhesives was analyzed and the preparation method was estimated through ATR-FTIR analysis.

The characteristic peaks of protein as well as carbohydrate were detected in the ATR-FTIR spectra of the adhesives joining the scrolls. They were not wheat starch adhesive, because the peaks for protein and carbohydrate were similar in intensity. Instead, they were assumed to be prepared from grains or beans that contain both protein and carbohydrate.

The ATR-FTIR spectra of grains such as rice flour, glutinous rice flour, and wheat flour, and of beans such as green bean powder, showed very strong characteristic peaks of carbohydrate. However, in the spectra of soybean powder and defatted soybean powder, which have a higher protein content than carbohydrate content, the peak intensities for the protein were similar or stronger than those of carbohydrate, signifying similar characteristics as those of the adhesives joining the scrolls. Furthermore, the peak for lipids did not appear in the spectra of defatted soybean powder and defatted soybean adhesive, and the spectra matched those of the adhesives joining the scrolls.

The peak for lipids did not appear in the 2nd derivative ATR-FTIR spectra for the adhesives joining the scrolls and defatted soybean powder adhesive. Furthermore, the peak for the carbonyl compound in the low-wavelength region due to the deterioration of the lipids in the high temperature and high humidity environment $\left(80^{\circ} \mathrm{C}, 80 \%\right)$ did not appear after accelerated deterioration(assuming deterioration over a long period of time).

The results suggest that the adhesives joining Buddhist scripture scrolls from the Goryeo Dynasty are soybean adhesives prepared from soybean-containing materials such as defatted soybean cake in which the oil has been completely squeezed out from the soybeans. Considering that soybean adhesive was also used to join Buddhist scriptures or books in the Nara period and Heian period of Japan, it can be inferred that in East Asia, soybean adhesive was widely used to join Buddhist scriptures until medieval times. 


\section{REFERENCES}

Cho, K.S., Lee, Y.H. and Jeong, B.J., 2010, The literature review on the traditional soybeans glues of Eastern Asia. The Dong Gook Sa Hak, 49, 377-298. (in Korean with Chinese abstract)

Chun, J.Y., 2006, A study on the adhesive used in Jang-Hwang of traditional paintings and calligraphics. The Review of Folk Life and Culture, 19, 29-58. (in Korean with English abstract)

Hayakawa, N., 2014, Analysis of an ancient adhesive, the so-called "Mamenori"(unfermented soybean paste). Science for Conservation, 53, 81-95. (in Japanese with English abstract)

Jang, G.I. and Im, B.H., 2003, A study on fermented soybean paste used in connection of the scroll type Tripitaka Koreana. Chemistry part, 49th National Science Contest, National Science Museum. (in Korean)

Lee, Y. H., 2010, Fundamental study for development of eco-friendly fermented traditional paste. National Science
Museum. (in Korean with Korean abstract)

Ohashi, Y., Obayashi, K. and Inaba, M., 2016, Soybean glue for ancient and medieval manuscripts: documents survey and trial manufacture of soybean glue. Bunkazaihozonshuhukugakaisi, 59, 1-8. (in Japanese with English abstract)

Okada, F. and Akimoto, S., 1998, Experimental reproduction of soybean paste described in ancient literature. Bunkazaihozonshuhukugakaisi, 42, 15-25. (in Japanese with English abstract)

Rural Development Administration, National Institute of Agricultural Sciences, 2013, Korean food composition table, 8th Revision.

Wang, Q., Sanad, W., Miller, L.M., Voigt, A., Klingel, K., Kandolf, R., Stangl, K. and Baumann, G., 2005, Infrared imaging of compositional changes in inflammatory cardiomyopathy. Vibrational Spectroscopy, 38, 217-222.

Wilson, R.H. and Belton, P.S., 1988, A fourier-transform infrared study of wheat starch gels. Carbohydrate Research, 180, 339-344. 